\title{
THE INFLUENCE OF THE SOLID WASTE LANDFILL EXISTENCE ON THE ENVIRONMENTAL AND ECONOMIC SITUATION OF PETRŮVKY VILLAGE (CZECHIA)
}

\author{
Veronika Lichovníková ${ }^{1}$, Milada Št'astná2 ${ }^{\text {, Jana Kotovicová3 }}{ }^{\text {, }}$ \\ Magdalena Vaverková ${ }^{4}$, Dana Adamcová ${ }^{5}$
}

Received 22 August 2015; Accepted 10 December 2015

Abstract: The landfill of municipal solid waste is a waste management equipment that can represent the risks to the environment because it serves a waste disposal, and thus there is a risk of potential leakage of undesirable substances into the surrounding (mainly aquaeous) environment. This risk is minimized when a precise construction and subsequent operation and closure of landfills are abided. And thus a negative impact on the surrounding components of the environment is eliminated. The landfill represents a considerable source of funds for the operating community. The acquired funds can then be used for the reconstruction of public municipal buildings, municipal greenery revitalization, maintainance of public utilities, or improvement of public amenities and as a support for voluntary associations. MWS Petrůvky is an example of such a waste disposal facility, which was founded in 1994 and whose operation is a significant income used to support rural development.

Key words: municipal solid waste, bioindicator, plant, Czech countryside

Abstrakt: Skládka tuhého komunálního odpadu je zařízení, které může představovat rizika pro životní prostředí. Ři provozování skládky a následném užavření existuje určité riziko možného úniku nežádoucích látek do okolí (hlavně voda) prostředí. Toto riziko je minimalizováno při striktním dodržení pavidel výstavby, následného provozu a uzavření skládky. Tím je dále dosažena eliminace negativních vlivů na okolní složky životního prostředí. Skládka představuje značný zdroj finančních prostředků pro provozující obec. Získané finanční prostředky mohou být použity na rekonstrukci veřejných obecních budov, revitalizaci obecní zeleně, opravy soukromých budov,

\footnotetext{
${ }^{1}$ Ing. Veronika Lichovníková, Faculty of Agronomy, Mendel University in Brno, Zemědělská 1, 61300 Brno, Czechia; e-mail: akinorev@seznam.cz

2 Doc. Ing. Milada Št'astná, Ph.D., Faculty of Agronomy, Mendel University in Brno, Zemědělská 1, 61300 Brno, Czechia; e-mail: stastna@mendelu.cz

3 Doc. RNDr. Jana Kotovicová, Ph.D. Faculty of Agronomy, Mendel University in Brno, Zemědělská 1, 61300 Brno, Czechia; e-mail: jana.kotovicova@mendelu.cz

4 Mgr. Ing. Magdalena Daria Vaverková, Ph.D., Faculty of Agronomy, Mendel University in Brno, Zemědělská 1, 61300 Brno, Czechia; e-mail: magdalena.vaverkova@mendelu.cz

${ }^{5}$ Bc. Ing. Dana Adamcová, Ph.D., Faculty of Agronomy, Mendel University in Brno, Zemědělská 1, 61300 Brno, Czechia; e-mail: dana.adamcova@mendelu.cz
} 
nebo zlepšení obecní vybavenosti, či jako finanční podpora dobrovolných spolků. Skládka TKO Petrůvky je příkladem takového zařízení k ukládání odpadu, které bylo založeno v roce 1994 a jehož provoz představuje významný príijem využitelný na podporu rozvoje venkova.

Klíčová slova: skládka tuhého komunálního odpadu, bioindkátor, rostlina, český venkov

\section{Introduction}

Petrůvky village is located in Českomoravská vrchovina in the south to southeast part of Vysočina region. The history of the village dates back to the $15^{\text {th }}$ century when the village was donated by the Laird of Třebíč hospital, where he was treated for leprosy. He also died of the disease in the village afterwards. The historical written sources point that from the village establishment local people lived on the cultivation of agricultural land or livestock breeding, two typical sources of income for the local area. Population in Petrúvky had been rising since its establishment until the 1920s, when the village was inhabited by 181 permanent citizens. Since twenties, the population declined until 1995 when Petrưvky was inhabited by only 66 people. Today, the abundance of the population increases again. In 2014 Petrůvky had 95 permanent inhabitants. In the 1990s the landfill of municipal solid waste (MSW Petrūvky) was established on the cadastral municipality of Petrüvky village. Undoubtedly, the landfill establishment near the village of Petrúvky was the object of many contradicting opinions, which either refused or promoted its foundation.

\section{The landfill establishment}

The MSW Petrůvky was founded in 1993 by the Union of municipalities "MSW landfill." The first section was put into the operation in February 1994. In the same year, the construction of the rest of the landfill body - sections 2-7 were finished. The project was supproted by the interest-free loan from the State Environmental Fund of The Czech Republic and the financial contribution of the founding villages. According to the landfill categorization based on the deposited waste, the Petrưvky landfill belongs to category 3 (waste with substantial propotrion of organic matter). The landfill body consists of $7+1$ sub - sections, 7 sections are currently in progress (cartridge 1-7). The capacity of the landfill is designed for about 118,000 residents which fall into the collecting area. The landfill area covers 72,130 square meters with a total volume of landfill space 600,000 cubic meters. The landfill body is bouned by a meadow from the southwest.The boundary between landfill area and meadow is formed by an unpaved road. North-eastern border represents a forest. The area delineated on the southeast is intended for the implementation of the landfill body extension (Fig. 1).
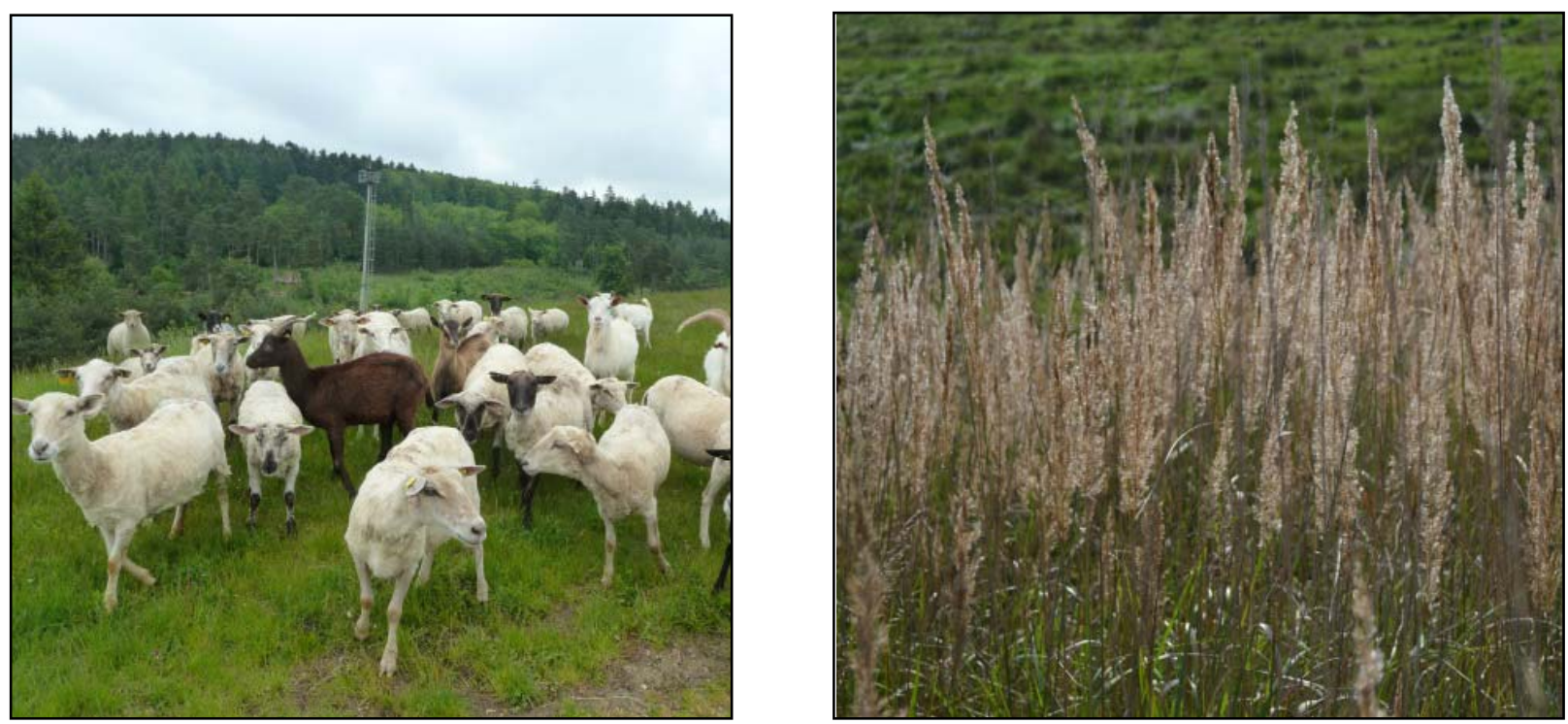

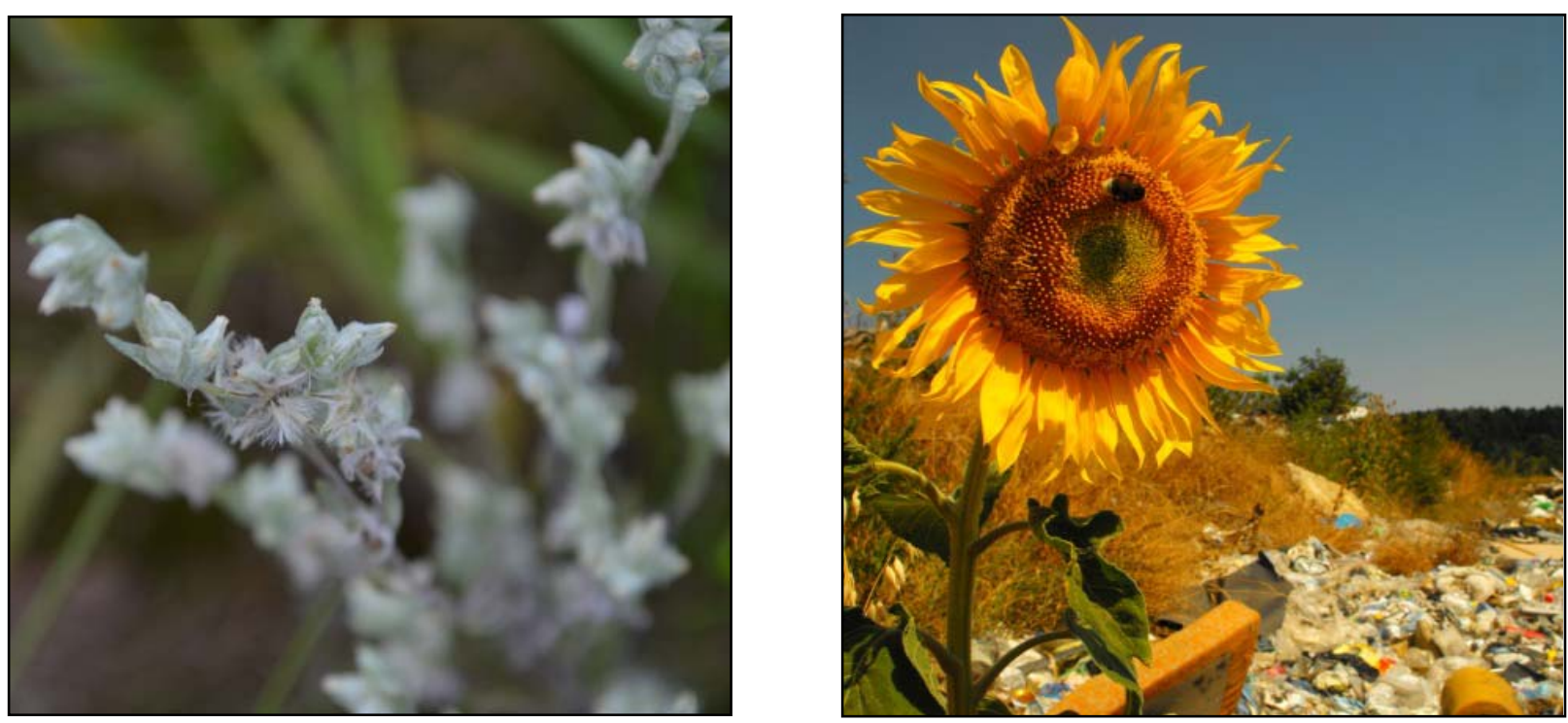

Fig 1. Certain aspects of landfill surrounding - pasture of goats and sheep on the revitalized landfill part; dominant species - reed grass (Calamagrostis epigejos); specially protected species Filago lutescens; vegetation growing on the landfill body. (Photo: V. Lichovníková)

The first phase of the landfill reclamation, was held in 2004, the reclaim of the 2nd stage was subsequently realized in 2006 . The service life of the landfill was set in 2020 , when projected capacity of $7+1$ sections will be filled. The construction of the planned 7 cartridges was realized in 1994, according to the project plan. During the building of the seven sections the expansion of one more section (the section no. 8) was already considered to be needed. New designed surface area represented 14,841 square meters, with a volume of landfill space 206,457 cubic meters. In November 2009, the Union of municipalities 'landfill TKO' submitted a request for the landfill area extention of the section no. 8. The newly planned section is located adjacent to from the north - west side of the existing landfilling area. The forest is located adjacent to the east side. The southern boundary represents an agricultural land and to the western side is the area of the planned completion cassette flanked by paved road. Completion of the new cartridge was established in 2011 and is projected on the total area of 37,873 square meters. The total area of the territory after the expansion and redesign of the landfill body is 85,345 square meters (Fig. 2). 


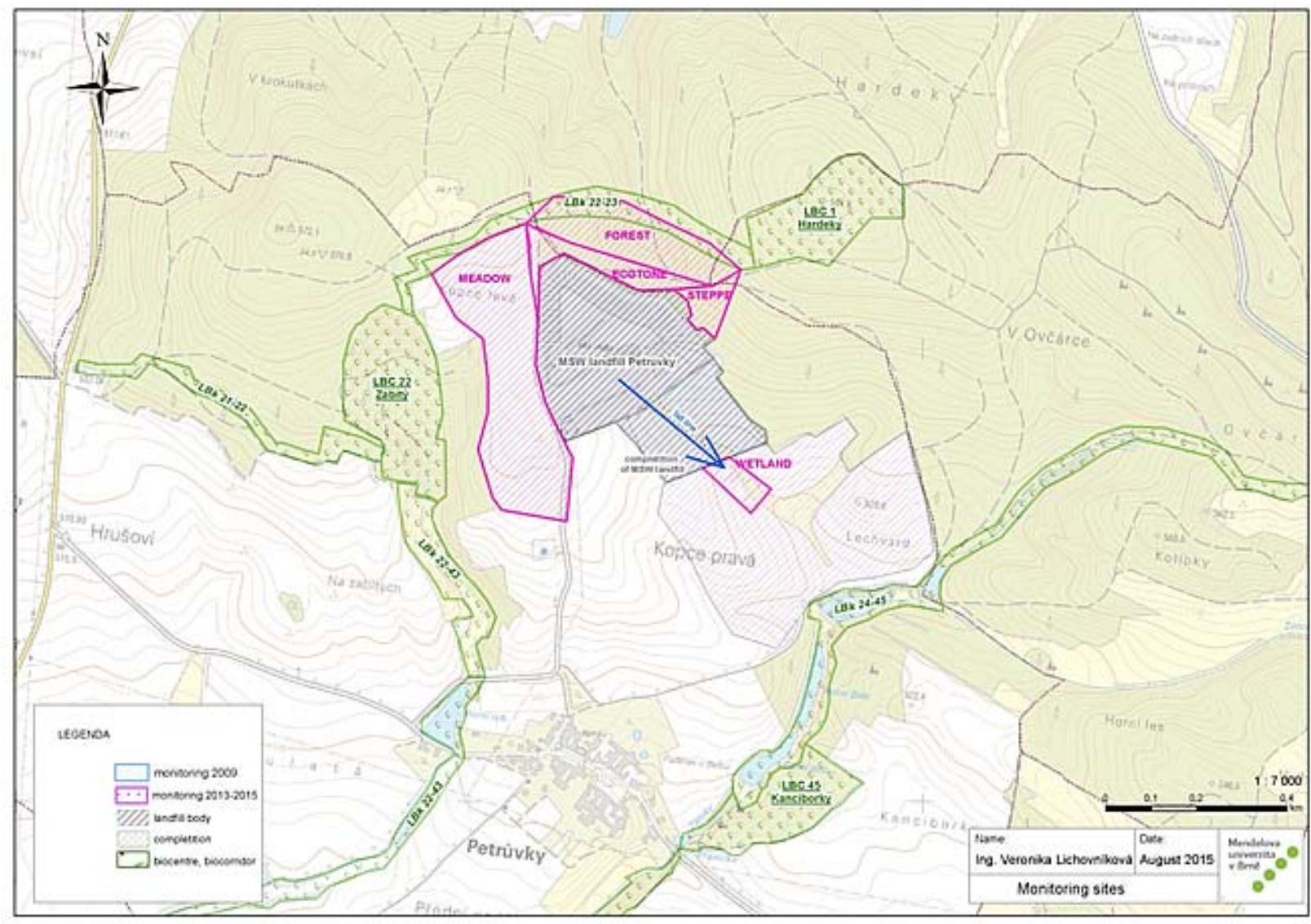

Fig 2. The map of landfill and observed sites.

\section{Environmental reflecion of landfill - MSW landfill as a research site}

Laner et al (2011) suggest that MSW landfill is supposed be continuously operated and controlled in order to avoid an adverse impact on human and the surrounding environment. According to Vaverková et al (2013) the impact assessment of the landfill on the environment can be carried out in several ways. To verify the safety of MSW landfill Petrüvky, the annual sampling and analysis of the surface and groundwater and soil from its immediate surroundings is supposed to be undertaken. Treweek in Paoli et al. (2012) considered reliable and regular environmental monitoring as an essential part of any process of assessing the impact of waste management on the environment. According to Tintner and Klug (2010) vegetation growing on the surface of the landfill is a good indicator of the state, because it reveals the comprehensive information on the status and development of the landfill. Kotovicová et al. (2011) suggest that the use of plants as bioindicators presents many advantages, such as low-cost option of longterm monitoring, or the simple availability of material. The study of plant bioindicators in the environmental assessment has been the subject of several years of the final thesis of postgradual students of the Institute of Applied and Landscape Ecology of the Faculty of Agronomy at Mendel University in Brno. Vaverková and Adamcová $(2009,2012,2013)$ has been dedicated to the utilization of vascular plant for a condition monitoring around the landfill. Any negative effect of the MSW landfill Petrúvky was also evaluated in the author's doctoral dissertation "Research into the utilization of plants as bio-indicators for the landfill monitoring". The main objective of this paper was to deepen the knowledge about the possibilities of using plant species as indicators of changes in the vicinity of the landfill. 


\section{Material}

Data were collected between 2013 - 2015 in five defined habitats - meadow, forest, ecotone, steppe and marsh (Fig. 3). During the monitoring period, 164 kinds of vascular plants were identified. Meadow habitat, stretching west of the landfill body, was formed by mesophilic meadow growths that are regularly mowed. The meadow is clearly manifested by narrow terrain depression, which indicated hygrophilous species and evergreen vegetation cover even in theperiods when the surrounding areas exhibited dry to sunburned vegetation due to water shortage and high summer temperatures. Ecotone formed the northern and northwestern rim of the studied area. Plant composition corresponded to the transition habitat between the meadow and forest. The forest shaped the northern border of the landfill area. Two different sub biotopes were identified in the forest biotope - the western side of the xeric vegetation and more humid nitrophilous part, which stretched eastward. Steppe habitat represented a smaller area with rocky subsoil, permeating up to the surface soil layers. Steppe was covered mostly by xeric species. Isolated marsh habitats were delimited under the landfill area in the territory where the nameless watercourse flows out of the landfill area.
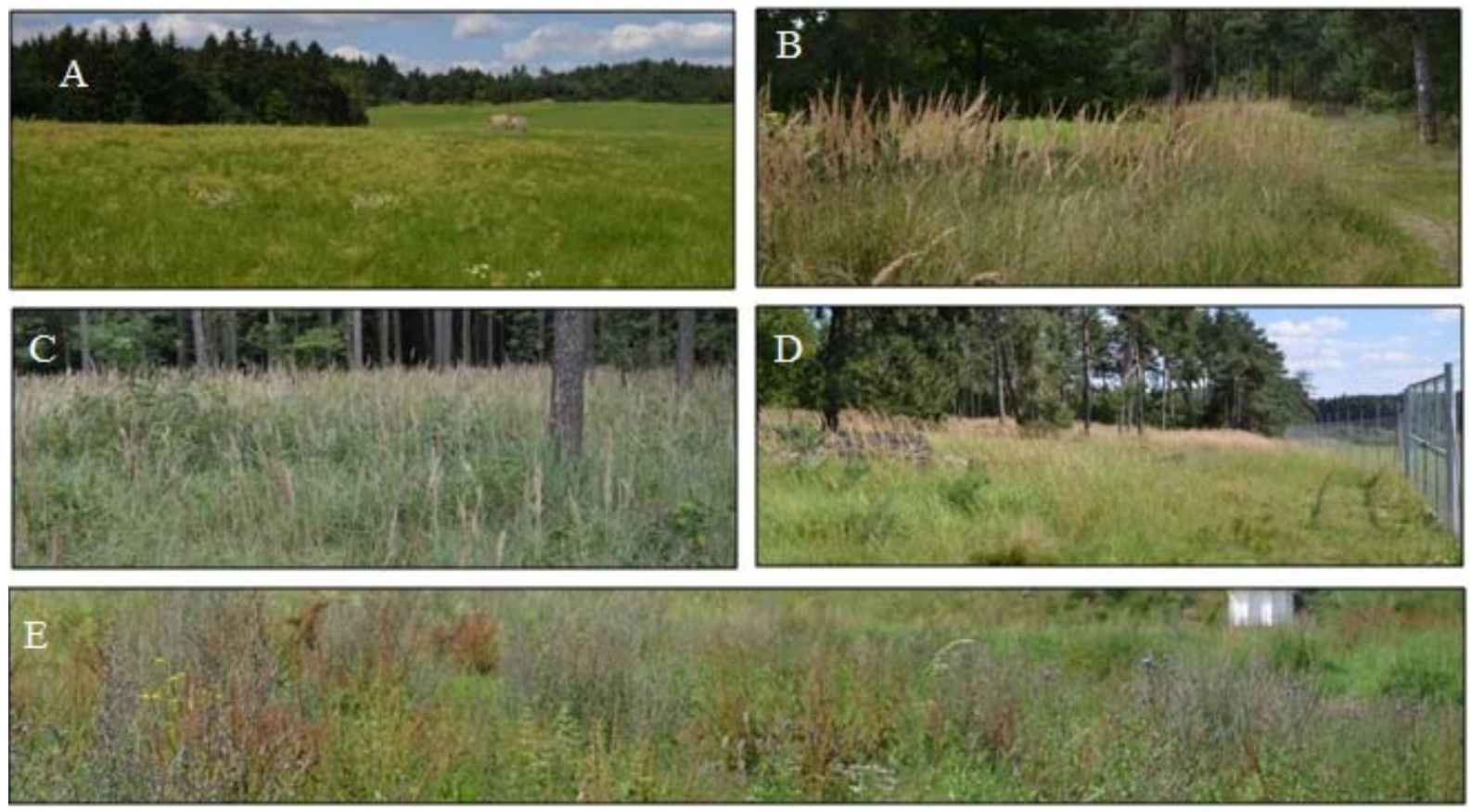

Fig 3. Monitored sites: $A$ - meadow, B-ecotone, $C$-forest, D-steppe, E-marsh. (Photo: V. Lichovníková)

The station exhibited nutrient-rich soil and water conditions. Fitter and Hay (2001) argue that in the growth conditions which are not set in the laboratory, ie. natural, outdoor conditions, species significantly exhibit different absorption of nutrients, growth and development. The profile of natural conditions therefore constitutes an integral part in assessing the occurrence and cover of plant species.

Characteristics of local hydrological and biogeographical biotic conditions were accompanied by a list of chemical properties of groundwater, surface water and soil from a landfill surrounding, which were obtained on the basis of regular surveillance analyses of the landfill.

\section{Methodology}

The in situ research was realized between 2013 - 2015 on five defined habitats - meadow, forest, ecotone, steppe, marsh, which were specific both visually and in the habitat conditions point of view. The position of the habitats in relation to the landfill is shown in Fig. 5. The monitoring of plant composition and species abundance at delimited and predefined sites 
was conducted in the period of three years. Each site was evaluated separately. Two methods were used in order to evaluate the results of the monitoring:

1) The scale of coverage according to the Braun - Blanquet (Hendrych, 1983) based on the quantification of the percentage of ground cover species:

- $R$ = infrequently (typically 1 plant), coverage is negligible)

- + = Scattered, negligible coverage

- 1 = scattered to fairly frequent coverage of $1-5 \%$

- $2 \mathrm{~m}=$ abundant coverage of approximately $5 \%$

$-2 a=$ coverage of $5-15 \%$

$-2 b=$ coverage of $15-25 \%$

$-3=$ coverage of $25-50 \%$

$-4=$ coverage of $50-75 \%$

- 5 = coverage of $75-100 \%$ (Westhoff, V. \& Van der Maarel, 1987)

2) Ecological requirements of each species, which were determined using the potential of local abiotic factors and their relationship to the landfill. Ecological requirements used in order to evaluate the certain environmental changes are given in Tab. 1.

\begin{tabular}{|c|c|c|c|c|c|c|}
\hline & 1 & 2 & 3 & 4 & 5 & 0 \\
\hline Temperature & $\begin{array}{l}\text { Very cold } \\
\text { areas }\end{array}$ & Cold areas & $\begin{array}{c}\text { Middle } \\
\text { temperature } \\
\text { areas }\end{array}$ & $\begin{array}{l}\text { Warm } \\
\text { areas }\end{array}$ & $\begin{array}{c}\text { The most } \\
\text { warm areas }\end{array}$ & indifferent \\
\hline Sunlight & $\begin{array}{l}\text { Deep } \\
\text { shadow } \\
\text { species }\end{array}$ & $\begin{array}{l}\text { Shady to } \\
\text { lighter } \\
\text { species }\end{array}$ & $\begin{array}{c}\text { Semi-shady } \\
\text { areas, } \\
\text { adaptable } \\
\text { species }\end{array}$ & $\begin{array}{l}\text { Semi - } \\
\text { sunny } \\
\text { species }\end{array}$ & $\begin{array}{l}\text { Sunny } \\
\text { species }\end{array}$ & indifferent \\
\hline Humidity & $\begin{array}{l}\text { Very dry } \\
\text { soil }\end{array}$ & Dry soil & $\begin{array}{c}\text { Intolerant to } \\
\text { drying and } \\
\text { waterlogging }\end{array}$ & $\begin{array}{l}\text { Moisture } \\
\text { soil }\end{array}$ & Wet soil & indifferent \\
\hline Soil reaction & $\begin{array}{l}\text { Very acid } \\
\text { soil }\end{array}$ & Acid soil & $\begin{array}{l}\text { Slightly acid } \\
\text { soil }\end{array}$ & $\begin{array}{c}\text { Acid to } \\
\text { neutral soil }\end{array}$ & Alcalic soil & indifferent \\
\hline Nitrogen & $\begin{array}{l}\text { Very low } \\
\text { nitrogen } \\
\text { content }\end{array}$ & $\begin{array}{c}\text { Slight } \\
\text { nitrogen } \\
\text { content }\end{array}$ & $\begin{array}{c}\text { Semi rich } \\
\text { nitrogen } \\
\text { content }\end{array}$ & $\begin{array}{c}\text { Rich } \\
\text { nitrogen } \\
\text { content }\end{array}$ & $\begin{array}{c}\text { Very rich } \\
\text { nitrogen } \\
\text { content }\end{array}$ & indifferent \\
\hline
\end{tabular}

Tab 1. Evaluation of plant ecological requirements (Ambros and Štykar, 2001).

\section{Results of research}

On specified sites, the composition of the monitored species was almost the same for the whole monioring period. In the case of species with very sporadic or rare occurance, individual fluctuations were detected. The fluctuation did not show at the specially protected species. Generally, each plant community showed a constant and stable coverage. All identified species were determined by their ecological requirements, which have pointed to the conditions in each habitat. The occurance of specially protected species was detected during the research: Filago lutescens, which, according to the Red List is classified to category C2 - highly endangered species and according to Decree no. 395/1992 Coll., as critically endangered species. Furthermore, Myosurus minimus belonging, according to the Red List, to category C3 endangered species, constantly occurred within the study area. Between 2014 and 2015 The occurrence of specially protected Myosotis discolour, Ranunculus auricomus and Veronica dillenii - representative of category C4 - species requiring attention were recorded. The occurance of specially protected Euphorbia amygdaloides and Filago arvensis (Fig. 4) was not determined with certainty (the designation of a particular species would require the botanical 
expertise), but because they are supposed to be the species mentioned above with special protection, they were placed on the list of identified species. The occurrence of specially protected species of vascular plants consider to be strong indicators of good state of the local environment, because their presence was recorded either constantly for three years, or had gradually emerged in this territory. During this research, none of the identified specially protected species has vanished, or expanded on the monitored sites.
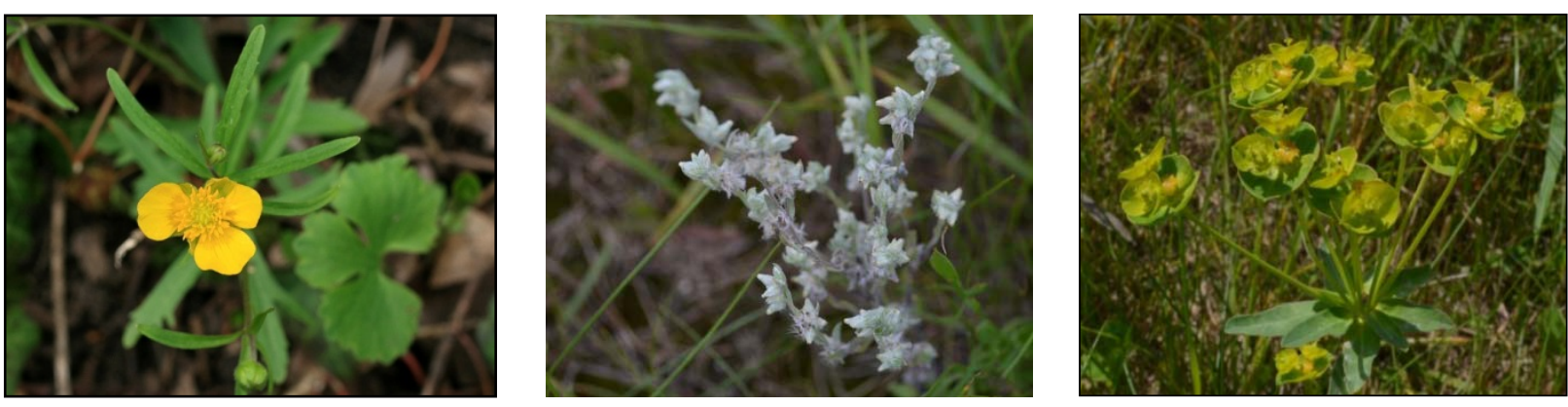

Fig 4. Some indentified specially protected species (Ranunculus auricomus, Filago arvesis, Euphorbia amygdaloides). (Photo: V. Lichovníková)

Nitrophilous species have proved to be suitable bioindicators for the landfill monitoring. Nitrophilous community situated in the LES habitat refered to the belonging to the botanical class Galio - Urticetea - Ruderal and semi nitrophilous perennial vegetation of wet locations. This vegetation class can occur either naturally, or as a result of increased nitrogen and phosphorus deposition.

The species occurrence on the Marsh site resulted in apparent higher nitrogen substances content in the surface water, which was, moreover, confirmed by laboratory analysis. Thus, the increased concentration of nitrogen substances had the direct impact on the increase of biomas growth of the identified nitrophilous species. However, higher concentrations of nitrogen compounds that were discovered in the water sample on the Marsh site to plant composition exhibited throughout whole observation period. Nevertheless no increase in the concentration was observed. Higher $\mathrm{N}$-substances concentration represented a potential risk of eutrophication of monitored riverstream. In order to determine the concentration of nitrogen compounds it would be useful to carry out more detailed analysis focused on the quality of surface water. The occurrence of specially protected species also highlighted the condition of the local environment, which confirmed that the MSW landfill Petrüvky has no negative impact on the environment. The plant species determined on the selected habitats are given in Tab. 2 .

Tab 2. The list of observed plant species identified on specified habitats.

\begin{tabular}{|l|c|c|c|c|c|}
\hline \multicolumn{1}{|c|}{ LATIN NAME } & MEADOW & ECOTONE & FOREST & STEPPE & MARSH \\
\hline Agrostis capillaris & 1 & 1 & 0 & 0 & 0 \\
\hline Achillea millefolium & 0 & 1 & 0 & 1 & 0 \\
\hline Ajuga reptans & 0 & 1 & 0 & 0 & 0 \\
\hline Allium oleraceum & 0 & 1 & 0 & 0 & 0 \\
\hline Alopecurus pratensis & 1 & 0 & 0 & 0 & 0 \\
\hline Anagalis arvensis & 1 & 0 & 0 & 0 & 0 \\
\hline Anthriscus sylvestris & 0 & 1 & 0 & 0 & 0 \\
\hline Anthemis arvensis & 1 & 0 & 0 & 0 & 0 \\
\hline Arabidopsis thaliana & 1 & 0 & 0 & 0 & 0 \\
\hline Arctium lappa & 0 & 0 & 1 & 0 & 0 \\
\hline Arctium tomentosum & 0 & 1 & 1 & 0 & 0 \\
\hline Arrhenatherum elatius & 0 & 1 & 1 & 1 & 0 \\
\hline
\end{tabular}




\begin{tabular}{|c|c|c|c|c|c|}
\hline Artemisia absinthium & 0 & 1 & 0 & 0 & 0 \\
\hline Artemisia vulgairs & 1 & 1 & 1 & 0 & 0 \\
\hline Astragalus glycyphyllos & 0 & 1 & 0 & 0 & 0 \\
\hline Barbarea vulgaris & 0 & 1 & 0 & 0 & 0 \\
\hline Bromus erectus & 0 & 0 & 0 & 0 & 1 \\
\hline Bromus hordeaceus & 0 & 1 & 1 & 1 & 0 \\
\hline Bromus sterilis & 0 & 0 & 1 & 0 & 0 \\
\hline Calamagrostis epigejos & 0 & 1 & 1 & 1 & 0 \\
\hline Calystegia sepium & 1 & 0 & 0 & 0 & 0 \\
\hline Capsella bursa-pastoris & 1 & 1 & 1 & 0 & 0 \\
\hline Cardamine pratensis & 1 & 0 & 0 & 0 & 0 \\
\hline Cardaria draba & 1 & 0 & 0 & 0 & 0 \\
\hline Carduus acanthiodes & 0 & 1 & 0 & 0 & 0 \\
\hline Carex pilosa & 0 & 0 & 1 & 0 & 0 \\
\hline Carex sylavatica & 0 & 1 & 0 & 0 & 0 \\
\hline Carlina acaulis & 1 & 0 & 0 & 0 & 0 \\
\hline Cerastium holosteoides & 1 & 0 & 0 & 0 & 0 \\
\hline Cirsium arvense & 0 & 1 & 0 & 0 & 1 \\
\hline Cirsium vulgare & 0 & 1 & 0 & 0 & 0 \\
\hline Clinopodium vulgare & 0 & 1 & 0 & 0 & 0 \\
\hline Convolvulus arvensis & 0 & 1 & 0 & 1 & 0 \\
\hline Conyza canadensis & 1 & 0 & 0 & 0 & 0 \\
\hline Dactylis glomerata & 1 & 1 & 1 & 1 & 0 \\
\hline Dianthus cartusianorum & 0 & 1 & 0 & 0 & 0 \\
\hline Dianthus deltoides & 0 & 0 & 1 & 0 & 0 \\
\hline Dryopteris filix - mas & 0 & 0 & 1 & 0 & 0 \\
\hline Echium vulgare & 0 & 1 & 0 & 1 & 0 \\
\hline Elytrigia repens & 0 & 0 & 1 & 0 & 0 \\
\hline Equisecum arvense & 1 & 0 & 0 & 0 & 0 \\
\hline Erodium cicutarium & 1 & 0 & 0 & 0 & 0 \\
\hline Elytrigia repens & 0 & 1 & 0 & 1 & 0 \\
\hline Erigeron annuus & 0 & 1 & 0 & 0 & 0 \\
\hline Eryngium campestre & 0 & 1 & 0 & 1 & 0 \\
\hline Euphorbia amygdaloides & 0 & 1 & 0 & 0 & 0 \\
\hline Euphorbia esula & 0 & 1 & 0 & 0 & 0 \\
\hline Fallopia convolvulus & 1 & 0 & 0 & 0 & 0 \\
\hline Festuca brevipila & 0 & 1 & 0 & 0 & 0 \\
\hline Festuca ovina & 0 & 0 & 1 & 0 & 0 \\
\hline Festuca pratensis & 0 & 0 & 0 & 0 & 1 \\
\hline Filago arvensis & 0 & 1 & 1 & $\mathbf{0}$ & 0 \\
\hline Filago lutescens & 1 & 0 & 0 & 0 & 0 \\
\hline Fragaria moschata & 0 & 0 & 1 & 0 & 0 \\
\hline Fragaria vesca & 1 & 1 & 1 & 0 & 0 \\
\hline Galeopsis pubescens & 1 & 1 & 1 & 0 & 0 \\
\hline Galium aparine & 0 & 1 & 1 & 0 & 0 \\
\hline Galium rotundifolium & 0 & 0 & 1 & 0 & 0 \\
\hline
\end{tabular}




\begin{tabular}{|c|c|c|c|c|c|}
\hline Galium verum & 0 & 1 & 0 & 0 & 0 \\
\hline Genista tinctoria & 0 & 1 & 0 & 0 & 0 \\
\hline Geranium robertianum & 0 & 0 & 1 & 0 & 0 \\
\hline Geum urbanum & 0 & 0 & 1 & 0 & 0 \\
\hline Glechoma hederacea & 0 & 0 & 1 & 0 & 0 \\
\hline Heracleum sphondylium & 0 & 1 & 0 & 0 & 0 \\
\hline Hieracium pilosella & 0 & 1 & 0 & 1 & 0 \\
\hline Hieracium murorum & 0 & 0 & 1 & 0 & 0 \\
\hline Hypericum hirsutum & 0 & 1 & 0 & 0 & 0 \\
\hline Geranium rotundifolium & 1 & 0 & 0 & 0 & 0 \\
\hline Gnaphalium uliginosum & 1 & 0 & 0 & 0 & 0 \\
\hline Hypericum perforatum & 1 & 1 & 1 & 1 & 0 \\
\hline Chenopodium album & 0 & 1 & 0 & 0 & 0 \\
\hline Impatiens parviflora & 0 & 1 & 1 & 0 & 0 \\
\hline Knautia arvensis & 0 & 1 & 1 & 1 & 0 \\
\hline Lamium album & 1 & 0 & 0 & 0 & 0 \\
\hline Lamium amplexicaule & 1 & 0 & 0 & 0 & 0 \\
\hline Lamium purpureum & 1 & 0 & 0 & 0 & 0 \\
\hline Lapsana communis & 0 & 0 & 1 & 0 & 0 \\
\hline Leucanthemum vulgare & 1 & 0 & 0 & 0 & 0 \\
\hline Linaria vulgaris & 1 & 0 & 0 & 0 & 0 \\
\hline Lolium perenne & 1 & 1 & 1 & 0 & 0 \\
\hline Lotus corniculatus & 0 & 1 & 0 & 0 & 0 \\
\hline Luzula campestris & 1 & 0 & 0 & 0 & 0 \\
\hline Luzula luzuloides & 0 & 0 & 1 & 0 & 0 \\
\hline Lychnis viscaria & 0 & 0 & 1 & 0 & 0 \\
\hline Maianthemum biolium & 0 & 0 & 1 & 0 & 0 \\
\hline Matricaria discoidea & 0 & 0 & 1 & 0 & 0 \\
\hline Medicago Iupulina & 0 & 0 & 0 & 0 & 0 \\
\hline Melica nutans & 0 & 1 & 1 & 0 & 0 \\
\hline Millium effusum & 0 & 0 & 1 & 0 & 0 \\
\hline Myosorus minimus & 1 & 0 & 0 & 0 & 0 \\
\hline Mycelis muralis & 0 & 0 & 1 & 0 & 0 \\
\hline Myosotis arvensis & 1 & 0 & 0 & 0 & 0 \\
\hline Myosotis discolor & 0 & 0 & 0 & 1 & 0 \\
\hline Oxalis acetosella & 0 & 0 & 1 & 0 & 0 \\
\hline Persicaria mitis & 0 & 1 & 1 & 0 & 0 \\
\hline Phleum pratense & 1 & 1 & 0 & 1 & 1 \\
\hline Pimpinella saxifraga & 0 & 1 & 0 & 0 & 0 \\
\hline Plantago lanceolata & 1 & 0 & 0 & 0 & 0 \\
\hline Plantago major & 1 & 0 & 1 & 0 & 0 \\
\hline Poa annua & 0 & 1 & 0 & 0 & 0 \\
\hline Poa trivialis & 0 & 1 & 0 & 0 & 0 \\
\hline Poa nemoralis & 0 & 1 & 1 & 0 & 0 \\
\hline Poa pratensis & 0 & 1 & 0 & 0 & 0 \\
\hline Poa trivialis & 0 & 0 & 1 & 0 & 0 \\
\hline
\end{tabular}




\begin{tabular}{|c|c|c|c|c|c|}
\hline Potentilla argentea & 1 & 1 & 1 & 1 & 0 \\
\hline Potentilla reptans & 0 & 1 & 0 & 0 & 0 \\
\hline Prunella vulgaris & 0 & 0 & 1 & 0 & 0 \\
\hline Ranunculus acris & 1 & 0 & 0 & 0 & 0 \\
\hline Ranunculus auricomus & 1 & 0 & 0 & 0 & 0 \\
\hline Rubus sp. & 0 & 1 & 1 & 1 & 0 \\
\hline Rumex acetosella & 0 & 1 & 1 & 0 & 0 \\
\hline Rumex crispus & 1 & 0 & 1 & 1 & 1 \\
\hline Rumex obtusifolius & 0 & 0 & 1 & 0 & 0 \\
\hline Salvia pratensis & 1 & 0 & 0 & 0 & 0 \\
\hline Sedum acre & 0 & 1 & 0 & 1 & 0 \\
\hline Securigera varia & 1 & 0 & 0 & 0 & 0 \\
\hline Senecio ovatus & 0 & 0 & 1 & 0 & 0 \\
\hline Setaria viridis & 1 & 0 & 0 & 0 & 0 \\
\hline Silene nutans & 0 & 0 & 1 & 0 & 0 \\
\hline Sinapis arvensis & 1 & 0 & 0 & 0 & 0 \\
\hline Stellaria holostea & 0 & 1 & 0 & 0 & 0 \\
\hline Stellaria media & 0 & 1 & 0 & 0 & 0 \\
\hline Symphytum officinale & 0 & 1 & 0 & 1 & 0 \\
\hline Tanacetum vulgare & 0 & 1 & 0 & 0 & 0 \\
\hline Taraxacum officinale & 0 & 0 & 1 & 0 & 0 \\
\hline Thlaspi arvense & 1 & 0 & 0 & 0 & 0 \\
\hline Thymus pulegioides & 0 & 0 & 0 & 1 & 0 \\
\hline Tragopogon dubius & 1 & 0 & 0 & 0 & 0 \\
\hline Traxacum offcinale & 1 & 0 & 0 & 0 & 0 \\
\hline Trifolium arvense & 1 & 1 & 0 & 0 & 0 \\
\hline Trifolium aureum & 0 & 1 & 0 & 0 & 0 \\
\hline Trifolium campestre & 1 & 0 & 0 & 0 & 0 \\
\hline Trifolium dubium & 1 & 0 & 0 & 0 & 0 \\
\hline Trifoium repens & 1 & 1 & 0 & 0 & 0 \\
\hline $\begin{array}{l}\text { Tripleurospermum } \\
\text { innodorum }\end{array}$ & 1 & 1 & 0 & 0 & 0 \\
\hline Urtica dioica & 0 & 1 & 0 & 0 & 1 \\
\hline Verbascum densiflorum & 1 & 0 & 0 & 0 & 0 \\
\hline Veronica agrestis & 1 & 0 & 0 & 0 & 0 \\
\hline Veronica dillenii & 0 & 0 & 1 & 0 & 0 \\
\hline Veronica chamaedris & 1 & 0 & 0 & 0 & 0 \\
\hline Veronica serpyllifolia & 1 & 0 & 0 & 0 & 0 \\
\hline Vicia angustifolia & 1 & 0 & 0 & 0 & 0 \\
\hline Vicia cracca & 0 & 1 & 0 & 0 & 0 \\
\hline Vicia hirsuta & 1 & 0 & 0 & 0 & 0 \\
\hline Vicia sepium & 0 & 1 & 0 & 0 & 0 \\
\hline Vicia Villosa & 0 & 0 & 1 & 0 & 0 \\
\hline Viola tricolor & 1 & 0 & 0 & 0 & 0 \\
\hline Acer platanoides & 0 & 0 & 1 & 0 & 0 \\
\hline Corylus avelana & 0 & 1 & 0 & 1 & 0 \\
\hline Crataegus cf. laevigata & 0 & 0 & 1 & 0 & 0 \\
\hline
\end{tabular}




\begin{tabular}{|l|l|l|l|l|l|} 
Cytisus nigricans & 0 & 1 & 0 & 0 & 0 \\
\hline Larix decidua & 0 & 0 & 1 & 0 & 0 \\
\hline Ligustrum vulgare & 0 & 1 & 0 & 0 & 0 \\
\hline Picea abies & 0 & 0 & 1 & 0 & 0 \\
\hline Pinus sylvestris & 0 & 1 & 1 & 1 & 0 \\
\hline Populus nigra & 0 & 1 & 0 & 1 & 0 \\
\hline Populus tremula & 0 & 0 & 1 & 0 & 0 \\
\hline Prunus avium & 0 & 0 & 1 & 0 & 0 \\
\hline Prunus spinosa & 0 & 1 & 0 & 1 & 0 \\
\hline Quercus petraea & 0 & 0 & 1 & 0 & 0 \\
\hline Quercus robur & 0 & 0 & 1 & 0 & 0 \\
\hline Rosa canina & 0 & 0 & 1 & 0 & 0 \\
\hline Salix euxina & 0 & 0 & 1 & 0 & 0 \\
\hline Sambucus nigra & 0 & 0 & 1 & 0 & 0 \\
\hline Sambucus racemosa & 0 & 0 & 1 & 0 & 0 \\
\hline Sorbus aucuparia & 0 & 0 & 1 & 0 & 0 \\
\hline Sorbus domestica & 0 & 0 & 1 & 0 & 0 \\
\hline Tilia cordata & 0 & 0 & 1 & 0 & 0 \\
\hline
\end{tabular}

\section{Economic reflection of landfill - financial source for broad innovations of public interests}

The union of landowners who manage their farms was founded after the transformation of homestead in Petrůvky. The local population was mostly made up of "immigrants" and the number of residents in the village was not high. The local population of indigenous inhabitants took the initiative to focus on the waste management as possibility of considerable economic gain. Possibility of establishing a municipal solid waste landfill was also offered to some of the surrounding villages, but they refused it. Representatives of the municipality subsequently also succeeded to convince the opponents of the plan implementation and landfill was subsequently established in 1994 and put into operation (Fig. 5).

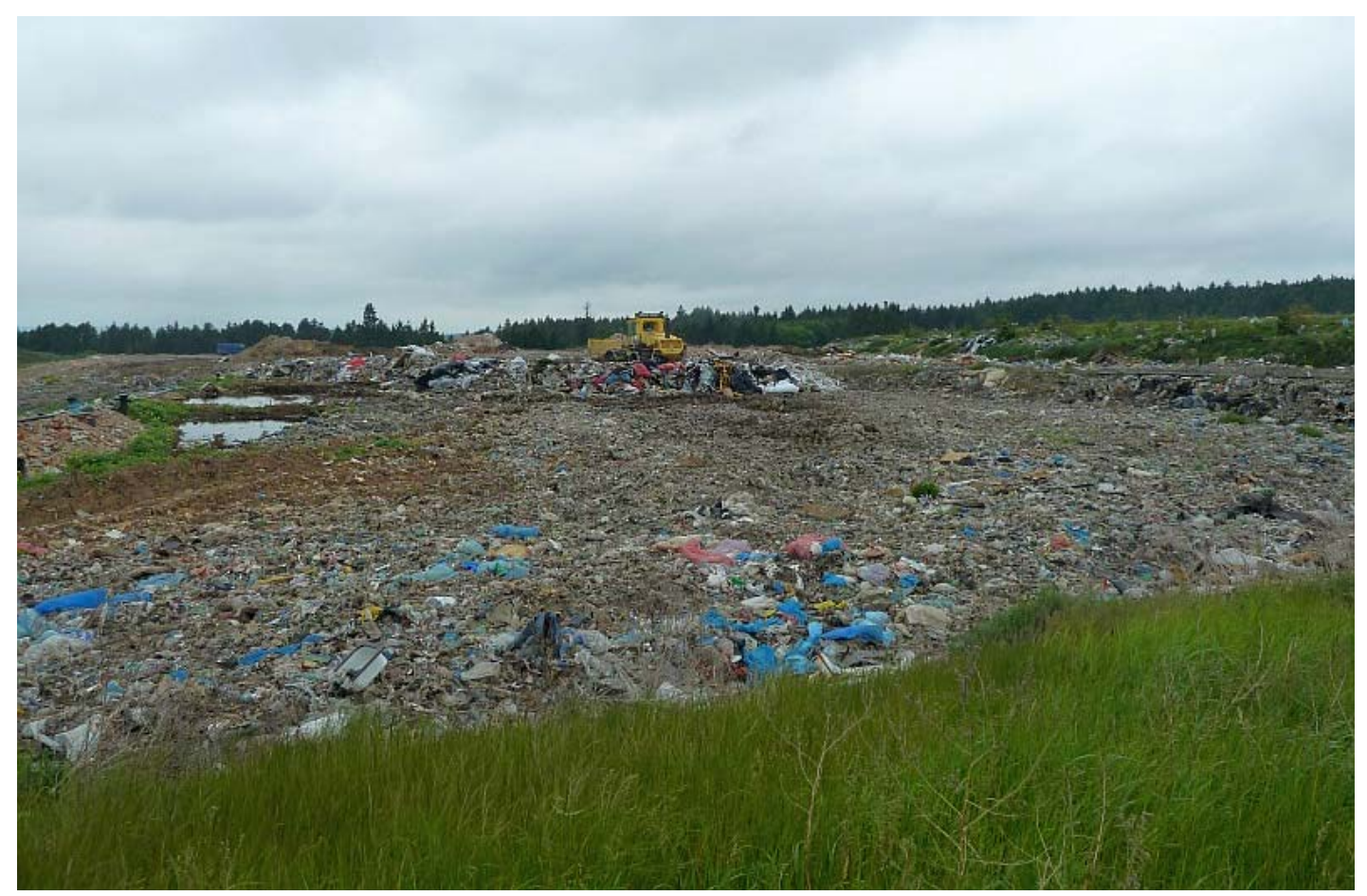

Fig 5. Municipal Solid Waste Petrůvky. (Photo: V. Lichovníková) 
The SPV (Special Purpose Vehicle) Petrůvky managed the landfill since its establishment. After the increase in the volume of activity within the landfill and inadequate operational possibilities of SPV Petrůvky, a newly founded association of municipalities "MSW Landfill" was established with the participation of 166 municipalities that took over operation of the landfill. The operation (ie. mostly waste collection) was ensured by the company ESKO-T. This company collects municipal waste from 80 municipalities.

The resulting amount of waste collected in the landfill represented a substantial income to municipal budget of Petrůvky village. Petrůvky community profits $18.5 €$ per one tonne of landfilled waste.

\section{Realized investments form acquired finance}

According to the current chairman of Petrůvky village, the municipality would not be able to realize large-scale projects for the improvement of the village or surrounding communities and to support organizations without the funds arising from the landfill. These funds coming into the municipal budget are an important source of income used for development of the municipality. The municipality built renovated potable water network, gas lines, sewers and roads with sidewalks thanks to the raised funds (Fig. 6).
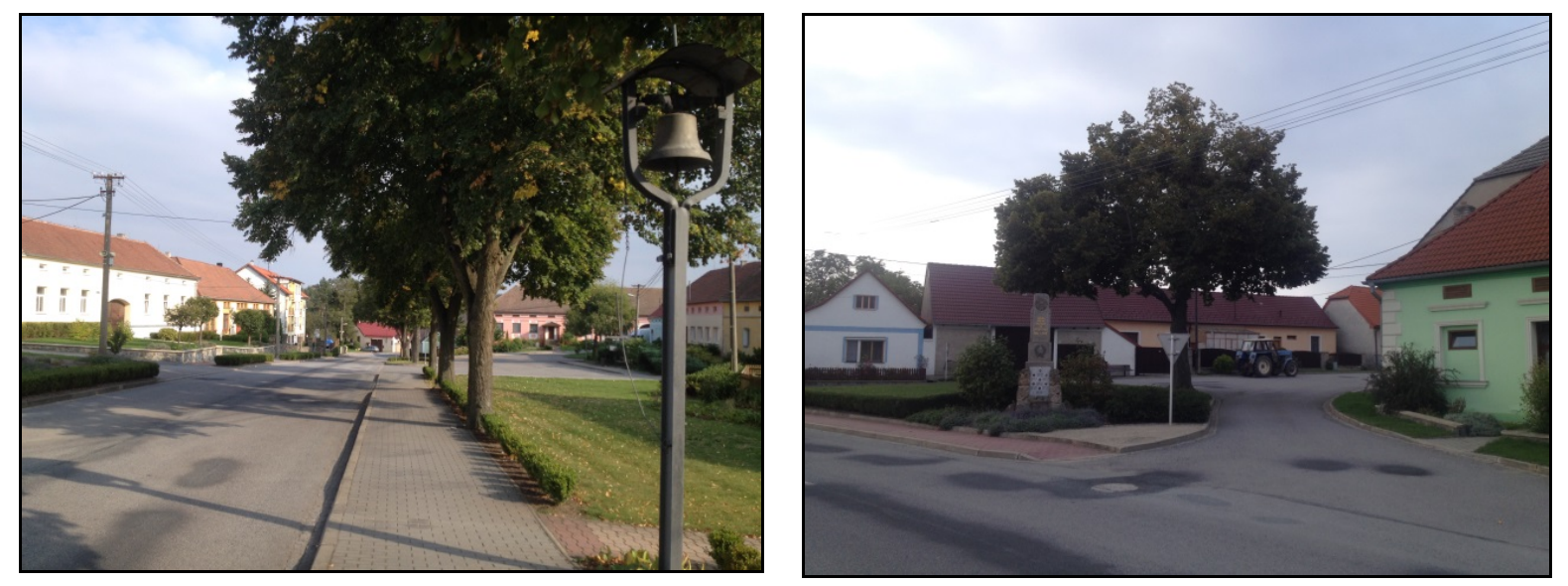

Fig 6. Reconstructed municipal square with a clinker. The linden tree after dendrological treatment. (Author: Veronika Lichovníková)

Funds were also invested in the revitalization of urban greenery. As part of the cultural background, the village invested in the construction of the local library with outdoor seating, which was built on the site of an old barn. In 2010, the local library was awarded as "The library of the Year 2010". The income from the landfill had significantly contributed to this award. Library activities do not lie only in the menu of book titles, but also in the implementation of public events for children and teens that would not have been implemented without financial subsidies. The library, for example, sponsored cultural events such as The Night with Hans Christian Anderson, The Lantern Procession, Easter whip braiding and associated Easter celebrations. The actual book collection is also sourced from the funds. The garage for urban garden equipment was also built in the area of the old barn. The reconstruction of the municipal office roof and the cultural house in Petruivky were also realized via the funds. In 2009, a revitalization of municipal greenery was completed. In 2015, a dendrologic survey of all trees in the village square was carried out. The survey resulted in the treatment of trees (mainly lime) and subsequent care of the selected trees. Obtained income from the landfill operation was also used for the dredging of two ponds. Primarily, the dam sealing of the Upper Lake was realized with an investment of about 100,000 CZK (equal to $3.700 €$ ). Afterwards, the removal of bottom mud was undertaken. Dredging up the Praslička pond was supported by approx. two million CZK. The municipality Petrůvky had applied the students of Secondary School of Civil Ingeneering in Trebic to visualize village houses in order to restore the fasades. Based on the project of visualizations, the houseowners could comment and further contribute to the modifying the projects. Subsequently, the acceptance of the proposal and the following reconstruction of their houses, which was funded by the Petrůvky community. The village 
Petrůvky also contributes to the completion of the city theatre in Třebíc $(2014,0.5$ mil. CZK; equal to $18.500 €$ ), to the NGOs activities for disabled citizens, to the elementary school Výčapy, to the parish of roman-catholic church in Lipník, and also to the irrigation equipment of football field in the Lipnik village. In 2011 and 2014, Petrůvky contributed 0.5 mil CZK (equal to $18.500 €)$ to the hospital in Trebíč. Community development is also reflected in the increasing number of building plots. In the southwestern part of the municipality Petrưvky, 18 new buildings containing developed utility networks (water, gas, electricity, storm and sanitary sewerage), were established.

\section{Conclusion}

The municipal waste landfill in Petrůvky facilitates disposal of waste from the surrounding area. Landfill is, according to the latest monitoring results of natural compounds operated and secured satisfactorily.

\begin{tabular}{|c|c|c|c|c|c|c|c|c|}
\hline \multirow{2}{*}{ Indicator } & \multirow{2}{*}{ Unit } & \multirow{2}{*}{ HI-1 } & \multirow{2}{*}{ HI-6 } & \multirow{2}{*}{ HV-8 } & \multirow{2}{*}{ HV-10 } & \multicolumn{3}{|c|}{ Limit values 1996} \\
\hline & & & & & & "A" & "B" & "C" \\
\hline $\mathrm{pH}$ & & 6,2 & 6,7 & 6,3 & 9,8 & - & - & - \\
\hline Konduktivita & $\mathrm{mS} / \mathrm{m}$ & 50,1 & 28,1 & 46,3 & 28,3 & - & - & - \\
\hline RAS & $\mathrm{mg} / \mathrm{l}$ & 180 & 100 & 170 & 110 & - & - & - \\
\hline $\mathrm{CHSK}_{\mathrm{Cr}}$ & $\mathrm{mgO}_{2} / \mathrm{l}$ & $<5$ & 36 & 9 & 10 & - & - & - \\
\hline $\mathrm{Ca}$ & $\mathrm{mg} / \mathrm{l}$ & 43,3 & 26,7 & 33,6 & 37,1 & - & - & - \\
\hline $\mathrm{Mg}$ & $\mathrm{mg} / \mathrm{l}$ & 19,5 & 11,8 & 22,9 & 9,2 & - & - & - \\
\hline $\mathrm{NH}_{4}{ }^{+}$ & $\mathrm{mg} / \mathrm{l}$ & $<0,05$ & $<0,05$ & $<0,05$ & $<0,05$ & 0,12 & 1,2 & - \\
\hline $\mathrm{NO}_{2}^{-}$ & $\mathrm{mg} / \mathrm{l}$ & $<0,065$ & $<0,065$ & $<0,065$ & $<0,065$ & 0,025 & 0,2 & - \\
\hline $\mathrm{NO}_{3}^{-}$ & $\mathrm{mg} / \mathrm{l}$ & 59,4 & 3,1 & 8,9 & $<2,0$ & - & - & - \\
\hline $\mathrm{Cl}^{-}$ & $\mathrm{mg} / \mathrm{l}$ & 33,0 & 6,4 & 35,5 & 16,0 & 25 & 100 & 150 \\
\hline $\mathrm{CN}^{-}$celk. & $\mathrm{mg} / \mathrm{l}$ & $<0,005$ & $<0,005$ & $<0,005$ & $<0,005$ & 0,01 & 0,1 & 0,2 \\
\hline Tenzidy aniontové & $\mathrm{mg} / \mathrm{l}$ & 0,059 & $<0,041$ & $<0,041$ & $<0,041$ & 0,020 & 0,250 & 0,500 \\
\hline $\mathrm{C}_{10}-\mathrm{C}_{40}$ & $\mathrm{mg} / \mathrm{l}$ & $<0,1$ & $<0,1$ & $<0,1$ & $<0,1$ & - & - & - \\
\hline As & $\mu \mathrm{g} / \mathrm{l}$ & 5,5 & $<5,0$ & $<5,0$ & $<5,0$ & 5 & 50 & 100 \\
\hline $\mathrm{Cd}$ & $\mu \mathrm{g} / \mathrm{l}$ & $<0,5$ & $<0,5$ & $<0,5$ & $<0,5$ & 1,5 & 5,0 & 20 \\
\hline $\mathrm{Cr}_{\text {celk }}$ & $\mathrm{mg} / \mathrm{l}$ & $<0,010$ & $<0,010$ & 0,024 & $<0,010$ & 0,003 & 0,15 & 0,3 \\
\hline $\mathrm{Cr}^{6+}$ & $\mathrm{mg} / \mathrm{l}$ & $<0,010$ & $<0,010$ & $<0,010$ & $<0,010$ & 0,001 & 0,035 & 0,075 \\
\hline $\mathrm{Cu}$ & $\mu \mathrm{g} / \mathrm{l}$ & $<3,0$ & 8,0 & 4,1 & $<3,0$ & 20 & 200 & 500 \\
\hline $\mathrm{Fe}$ & $\mathrm{mg} / \mathrm{l}$ & 0,102 & 0,197 & 0,676 & 0,173 & - & - & - \\
\hline $\mathrm{Hg}$ & $\mu \mathrm{g} / \mathrm{l}$ & $<0,20$ & $<0,20$ & $<0,20$ & $<0,20$ & 0,1 & 2,0 & 5,0 \\
\hline Mn & $\mathrm{mg} / \mathrm{l}$ & 0,284 & 0,0341 & 0,254 & 0,513 & - & - & - \\
\hline $\mathrm{Pb}$ & $\mu \mathrm{g} / \mathrm{l}$ & $<5,0$ & $<5,0$ & $<5,0$ & $<5,0$ & 20 & 100 & 200 \\
\hline 1,1-DCE & $\mu \mathrm{g} / \mathrm{l}$ & $<0,2$ & $<0,2$ & $<0,2$ & $<0,2$ & 0,1 & 10 & 20 \\
\hline trans-1,2 DCE & $\mu \mathrm{g} / \mathrm{l}$ & $<0,2$ & $<0,2$ & $<0,2$ & $<0,2$ & 0,1 & 25 & 50 \\
\hline cis-1,2 -DCE & $\mu \mathrm{g} / \mathrm{l}$ & $<0,2$ & $<0,2$ & $<0,2$ & $<0,2$ & 0,1 & 25 & 50 \\
\hline TCE & $\mu \mathrm{g} / \mathrm{l}$ & $<0,1$ & $<0,1$ & $<0,1$ & $<0,1$ & 0,1 & 25 & 50 \\
\hline PCE & $\mu \mathrm{g} / \mathrm{l}$ & $<0,1$ & $<0,1$ & $<0,1$ & $<0,1$ & 0,1 & 10 & 20 \\
\hline Delor 103 & $\mu \mathrm{g} / \mathrm{l}$ & $<0,01$ & $<0,01$ & $<0,01$ & $<0,01$ & - & - & - \\
\hline Delor 106 & $\mu \mathrm{g} / \mathrm{l}$ & $<0,01$ & $<0,01$ & $<0,01$ & $<0,01$ & - & - & - \\
\hline Suma PCB & $\mu \mathrm{g} / \mathrm{l}$ & $<0,010$ & $<0,010$ & $<0,010$ & $<0,010$ & 0,01 & 0,25 & 1,0 \\
\hline Antracen & $\mu \mathrm{g} / \mathrm{l}$ & $<0,005$ & $<0,005$ & $<0,005$ & $<0,005$ & 0,005 & 5 & 10 \\
\hline Fluoranten & $\mu \mathrm{g} / \mathrm{l}$ & $<0,005$ & $<0,005$ & $<0,005$ & $<0,005$ & 0,03 & 25 & 50 \\
\hline Naftalen & $\mu \mathrm{g} / \mathrm{l}$ & 0,043 & 0,039 & 0,017 & $<0,005$ & 0,1 & 25 & 50 \\
\hline Fenantren & $\mu \mathrm{g} / \mathrm{l}$ & $<0,005$ & $<0,005$ & $<0,005$ & 0,006 & 0,005 & 5 & 10 \\
\hline Pyren & $\mu \mathrm{g} / \mathrm{l}$ & $<0,005$ & $<0,005$ & $<0,005$ & $<0,005$ & 0,1 & 25 & 50 \\
\hline
\end{tabular}

Tab 3. Results of chemical analyzes of groundwater samples from March 2014 and compared with the limit values according to the Guideline of Ministry of Enviromnent (1996). 
According to the results of the laboratory analysis, it is clear, that groundwater, surface water and soil samples (Tab. 3, 4, 5) taken periodically correspond to the limits laid down for "A" criterion "A" (The Methodical Guidance of the Ministry of Environment - Criteria of contamination of soils and groundwater), corresponding approximately to the natural content of substances of concern in the nature.

Only the analysis of surface water has been found to have higher concentrations of COD, $\mathrm{CHSK}_{\mathrm{Cr}}, \mathrm{N}-\mathrm{NH}_{4}{ }^{+}, \mathrm{N}-\mathrm{NO}_{3}{ }^{-}$and $\mathrm{Mn}$, which indicate a slight deterioration in the surfacewater quality.

However, higher concentrations of nitrogen compounds that were discovered at the site of MARSH habitat, to plant composition exhibited throughout the observation. Therefore increased concentrations of these substances were not observed.

\begin{tabular}{|c|c|c|c|c|c|c|c|}
\hline \multirow{2}{*}{ Indicator } & \multirow{2}{*}{ Unit } & \multicolumn{5}{|c|}{ Year } & \multirow{2}{*}{ GR No. 61/2003 } \\
\hline & & 2010 & 2011 & 2012 & 2013 & 2014 & \\
\hline $\mathrm{pH}$ & & 6,7 & 7,37 & 7,36 & 7,4 & 7,4 & 6-9 \\
\hline Konduktivita & $\mathrm{mS} / \mathrm{m}$ & 27,9 & 39,3 & 63,4 & 37,9 & 92,5 & - \\
\hline RAS & $\mathrm{mg} / \mathrm{l}$ & 147 & 190 & 330 & 110 & 420 & - \\
\hline CHSK $_{\mathrm{Cr}}$ & $\mathrm{mgO}_{2} / \mathrm{l}$ & 43 & 24 & 32 & 32 & 28 & 26 \\
\hline $\mathrm{Ca}$ & $\mathrm{mg} / \mathrm{l}$ & 32,3 & 35,0 & 58,7 & 29,2 & 62,9 & 190 \\
\hline $\mathrm{Mg}$ & $\mathrm{mg} / \mathrm{l}$ & 12,5 & 18,9 & 20,4 & 13,7 & 37,2 & 120 \\
\hline $\mathrm{N}-\mathrm{NH}_{4}{ }^{+}$ & $\mathrm{mg} / \mathrm{l}$ & 1,07 & $<0,040$ & 0,519 & $<0,040$ & 0,113 & 0,23 \\
\hline $\mathrm{N}-\mathrm{NO}_{2}{ }^{-}$ & $\mathrm{mg} / \mathrm{l}$ & 0,023 & $<0,02$ & $<0,02$ & $<0,02$ & 0,03 & - \\
\hline $\mathrm{N}^{-\mathrm{NO}_{3}}{ }^{-}$ & $\mathrm{mg} / \mathrm{l}$ & 4,13 & 4,8 & 3,2 & 4,2 & 10,2 & 5,4 \\
\hline $\mathrm{Cl}^{-}$ & $\mathrm{mg} / \mathrm{l}$ & 18,4 & 23,8 & 49,8 & 27,3 & 97,9 & 150 \\
\hline $\mathrm{CN}^{-}$celk. & $\mathrm{mg} / \mathrm{l}$ & $<0,005$ & $<0,005$ & $<0,005$ & $<0,005$ & 0,006 & 0,3 \\
\hline Tenzidy anio. & $\mathrm{mg} / \mathrm{l}$ & $<0,04$ & $<0,041$ & $<0,041$ & $<0,041$ & $<0,041$ & 0,3 \\
\hline NEL & $\mathrm{mg} / \mathrm{l}$ & $<5,0$ & $<5,0$ & $<5,0$ & $<5,0$ & $<5,0$ & - \\
\hline C10-C40 & $\mathrm{mg} / \mathrm{l}$ & - & - & - & - & $<0,1$ & 0,1 \\
\hline As & $\mu \mathrm{g} / \mathrm{l}$ & $<0,70$ & $<0,3$ & $<0,3$ & $<0,3$ & $<0,3$ & 11 \\
\hline $\mathrm{Cd}$ & $\mu \mathrm{g} / \mathrm{l}$ & $<0,010$ & 0,022 & 0,014 & $<0,010$ & $<0,010$ & 0,3 \\
\hline $\mathrm{Cr}_{\text {celk. }}$ & $\mathrm{mg} / \mathrm{l}$ & $<0,010$ & $<0,010$ & $<0,010$ & $<0,010$ & $<0,010$ & 0,018 \\
\hline $\mathrm{Cr}^{6+}$ & $\mathrm{mg} / \mathrm{l}$ & $<0,010$ & $<0,010$ & $<0,010$ & $<0,010$ & $<0,010$ & - \\
\hline $\mathrm{Cu}$ & $\mu \mathrm{g} / \mathrm{l}$ & 0,352 & 1,72 & 0,615 & 0,088 & 0,070 & 14 \\
\hline $\mathrm{Fe}$ & $\mathrm{mg} / \mathrm{l}$ & $<0,20$ & $<0,05$ & $<0,05$ & $<0,05$ & $<0,05$ & 1 \\
\hline $\mathrm{Hg}$ & $\mu \mathrm{g} / \mathrm{l}$ & $<0,2$ & $<0,05$ & $<0,05$ & $<0,05$ & $<0,05$ & 0,05 \\
\hline $\mathrm{Mn}$ & $\mathrm{mg} / \mathrm{l}$ & 0,197 & 0,094 & 0,686 & $<0,02$ & 0,126 & 0,3 \\
\hline $\mathrm{Pb}$ & $\mu \mathrm{g} / \mathrm{l}$ & $<0,05$ & $<0,1$ & $<0,1$ & $<0,1$ & $<0,1$ & 7,2 \\
\hline 1,1-DCE & $\mu \mathrm{g} / \mathrm{l}$ & $<0,1$ & $<0,2$ & $<0,2$ & $<0,2$ & $<0,2$ & - \\
\hline trans1,2DCE & $\mu \mathrm{g} / \mathrm{l}$ & $<0,1$ & $<0,2$ & $<0,2$ & $<0,2$ & $<0,2$ & - \\
\hline cis-1,2 -DCE & $\mu \mathrm{g} / \mathrm{l}$ & $<0,1$ & $<0,2$ & $<0,2$ & $<0,2$ & $<0,2$ & 1 \\
\hline TCE & $\mu \mathrm{g} / \mathrm{l}$ & $<0,1$ & $<0,1$ & $<0,1$ & $<0,1$ & $<0,1$ & 10 \\
\hline PCE & $\mu \mathrm{g} / \mathrm{l}$ & $<0,1$ & $<0,1$ & $<0,1$ & $<0,1$ & $<0,1$ & 10 \\
\hline Delor 103 & $\mu \mathrm{g} / \mathrm{l}$ & $<0,01$ & $<0,0007$ & 0,002 & $<0,001$ & $<0,010$ & - \\
\hline Delor 106 & $\mu \mathrm{g} / \mathrm{l}$ & $<0,01$ & 0,1517 & 0,001 & $<0,001$ & $<0,010$ & - \\
\hline Suma PCB & $\mu \mathrm{g} / \mathrm{l}$ & - & - & $<0,007$ & $<0,010$ & $<0,010$ & 0,007 \\
\hline Antracen & $\mu \mathrm{g} / \mathrm{l}$ & $<0,002$ & $<0,010$ & $<0,01$ & $<0,01$ & $<0,010$ & 0,1 \\
\hline Fluoranten & $\mu \mathrm{g} / \mathrm{l}$ & $<0,002$ & $<0,010$ & $<0,01$ & $<0,01$ & $<0,010$ & 0,1 \\
\hline Naftalen & $\mu \mathrm{g} / \mathrm{l}$ & - & $<0,010$ & $<0,01$ & $<0,01$ & 0,027 & 2,4 \\
\hline Pyren & $\mu \mathrm{g} / \mathrm{l}$ & - & $<0,010$ & $<0,01$ & $<0,01$ & $<0,010$ & - \\
\hline Fenantren & $\mu \mathrm{g} / \mathrm{l}$ & - & $<0,010$ & $<0,01$ & $<0,01$ & $<0,010$ & 0,03 \\
\hline
\end{tabular}

Tab 4. Results of the chemical analyzes of surface water samples in the period 2010 to 2014 compared with the limit values according to the Guideline of Ministry of Enviromnent (1996). 


\begin{tabular}{|c|c|c|c|c|c|c|c|}
\hline \multirow{2}{*}{ Indicator } & \multirow{2}{*}{ Units } & \multirow{2}{*}{$\begin{array}{c}\mathrm{A}-1 \\
(0,0-0,1 \mathrm{~m})\end{array}$} & \multirow{2}{*}{$\begin{array}{c}\mathrm{B}-1 \\
(\mathbf{0 , 0 - 0 , 1} \mathbf{~ m})\end{array}$} & \multirow{2}{*}{$\begin{array}{c}\mathrm{C}-1 \\
(\mathbf{0 , 0}-\mathbf{0 , 1} \mathbf{~ m})\end{array}$} & \multicolumn{3}{|c|}{ Limit values 1996} \\
\hline & & & & & „A“ & „B“ & „C“ \\
\hline As & mg/kg/dry mat. & 16,2 & 22,9 & 30,1 & 30 & 65 & 140 \\
\hline $\mathrm{Ba}$ & mg/kg/dry mat. & 156 & 175 & 175 & 600 & 900 & 2800 \\
\hline $\mathrm{Be}$ & mg/kg/dry mat. & $<2,0$ & $<2,0$ & $<2,0$ & 5 & 15 & 30 \\
\hline $\mathrm{Cd}$ & mg/kg/dry mat. & 0,58 & 0,23 & 0,26 & 0,5 & 10 & 30 \\
\hline Co & mg/kg/dry mat. & 25,2 & 32,3 & 30,3 & 25 & 180 & 450 \\
\hline $\mathrm{Cr}^{6+}$ & mg/kg/dry mat. & $<0,2$ & $<0,2$ & $<0,2$ & 2 & 12 & 50 \\
\hline $\mathrm{Cu}$ & mg/kg/dry mat. & 25,2 & 33,1 & 33,0 & 70 & 500 & 1500 \\
\hline $\mathrm{Hg}$ & mg/kg/dry mat. & 0,050 & 0,047 & 0,040 & 0,4 & 2,5 & 20 \\
\hline Mo & mg/kg/dry mat. & $<1,0$ & $<1,0$ & $<1,0$ & 0,8 & 50 & 240 \\
\hline $\mathrm{Pb}$ & mg/kg/dry mat. & 41,6 & 46,4 & 38,7 & 80 & 250 & 800 \\
\hline Sn & mg/kg/dry mat. & $<100$ & $<100$ & $<100$ & 15 & 200 & 600 \\
\hline $\mathrm{V}$ & mg/kg/dry mat. & 69,7 & 96,3 & 93,6 & 180 & 340 & 550 \\
\hline $\mathrm{Zn}$ & mg/kg/dry mat. & 112 & 123 & 107 & 150 & 1500 & 5000 \\
\hline NEL & mg/kg/dry mat. & 68 & 58 & 48 & 100 & 500 & 1000 \\
\hline $\mathrm{CN}_{\text {celk. }}$ & mg/kg/dry mat. & $<1,00$ & $<1,00$ & $<1,00$ & 7 & 15 & 75 \\
\hline $\mathrm{CN}_{\text {tox. }}$ & mg/kg/dry mat. & $<1,00$ & $<1,00$ & $<1,00$ & 1,5 & 8 & 30 \\
\hline Fenoly & mg/kg/dry mat. & $<5,00$ & $<5,00$ & $<5,00$ & 0,05 & 25 & 120 \\
\hline
\end{tabular}

Tab 5. Results of chemical analyzes of soil in 2009 and the result comparison with the limit values according to the Guideline of Ministry of Enviromnent (1996).

Good condition of the surrounding environment has also been demonstrated by the research within the thesis "Research into the use of biomarkers for monitoring of landfills". The occurrence of specially protected species also highlighted the good condition of the local environment, which contributed to the statement that the landfill MSW Petrúvky has no negative impact on the environment. However, to support the overal environmental issue and claim no impact occurs, more detailed soil and water analyses are needed. Economic benefits for the community Petrůvky and the surrounding community is an important source of funds that are heavily invested in community development and for the support for non-profit organizations, sports clubs, cultural associations and community facilities. The way in which received funds are used, has a very positive effect on the development of the adjacent rural Třebíč.

References

[1] Aichele, D. \& Golteová-Bechtleová, M. (2005). Co tu kvete; Kvetoucí rostliny střední Evropy ve volné prírodě. Praha: Euromedia Group.

[2] Ambros, Z. (1985). Bioindikace abiotického prostředí lesných ekosytémů. Brno: Acta universitatis agriculturae Facultas silviculturae, 54(3-4), 367-391.

[3] Antonín, V. \& Bieberová, Z. (1995). Chráněné houby ČR. Praha: Ministry of Environment in collaboration with Agency of Nature and Landscape Protection.

[4] Deyl, M. \& Hísek, K. (1973). Naše květiny I. Praha: Albatros.

[5] Fitter, A. H. \& Hay, R. K. M. (2001). Environmental Physiology of Plants. $3^{\text {rd }}$ ed. Waltham (Mass.): Academic Press.

[6] Hendrych, R. (1983). Fytocenologie. Praha: SPN.

[7] Kotovicová, J., Toman, F., Vaverková, M. \& Stejskal, B. (2011). Evaluation of waste landfills' impact on the environment using bioindicators. Polish Journal of Environmental Studies 20(2), 371- 377. 
[8] Laner, D., Crest, M., Scharft, H., Morris, J. W. F., Bailar, M. A. (2012). A review of approaches for the long-term management of municipal solid waste landfills. Waste management, 32(3), 498-512. DOI:10.1016/j.wasman.2011.11.010.

[9] Paoli, L., Corsini, A., Bigagli, V., Vannini, J., Bruscoli, C., Loppi, S. (2012). Long-term biological monitoring of environmental quality around a solid waste landfill assessed with lichens. Environmental Pollution, 161(70-75). DOI:10.1016/j.envpol.2011.09.028.

[10] Schauer, T. (2007). Svět rostlin; 1150 květin, trav, travin, stromů a keřu střední Evropy. Praha: REBO Production.

[11] Šindelářová, J. \& Regal, V. (1970). Atlas nejdůležitějších trav. Praha: Knihtisk MíR.

[12] Vaverková, M. (2009). Možnosti využití bioindikátorů v okolí skládky ve Štěpánovicích. [Doctoral thesis]. Brno: Mendel University.

[13] Vaverková, M. \& Adamcová, D. (2012). Potential impact of two landfills on the near vicinity with the use of bioindicators. Infrastruktura i Ekologia Terenów Wiejskich, 4(1), 15-25.

[14] Vaverková, M., et al. (2013). Verifying research of waste landfill environmental impact using bioindicators. Polish Journal of Environmental Studies, 22(2), 15-25.

[15] Vaverková, M., Toman, F. \& Kotovicová, J. (2012). Research into the occurence of some plantspecies as indicators of landfill impact on the environment. Polish Journal of Environmental Studies, 21(3), 755-762.

[16] Vaverková, M., Adamcová, D. \& Toman, F. (2013). Verification of the occurance of some plant species as indicators of landfill impact on the environment. Acta Universitas Agriculturae et Silviculturae Mendelianae Brunensis 61(5), 1441-1450. DOI: 10.11118/actaun201361051441.

[17] Westhoff, V. \& Van der Maarel, E. (1978). The Braun-Blanquet approach (pp. 289-399). In: Whittaker, R. H., ed., Classification of plant communities. 's-Gravenhage: W. Junk.

[18] Tintner, J. \& Klug, B. (2011). Can vegetation indicate landfill cover features? Flora 206(6), 559 - 566. DOI: 10.1016/j.flora.2011.01.005. 